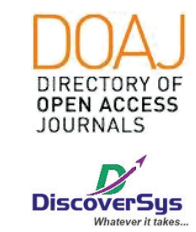

Published by DiscoverSys

\section{Pola Mikroba dan Sensitivitasnya Terhadap Antibiotik pada Pasien dengan Infeksi Saluran Kemih di RSUD Prof. Dr. W.Z. Johannes, Kupang Periode Januari-Desember 2017}

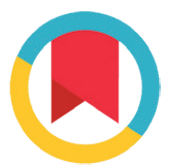

CrossMark

\author{
Vivi Anggelia, ${ }^{1 *}$ Clarissa Oktavia, ${ }^{2}$ Heri Sutrisno, ${ }^{3}$ Hermi Indita ${ }^{4}$
}

\title{
ABSTRACT
}

Background: Urinary tract infection (UTI) is a serious public health problem which involves infection of any parts of the urinary tract. In the past few years, treatment of UTI becomes very challenging due to increase emergence of antibiotics resistance in uro-pathogens. This study was performed to determine microbial patterns and its sensitivity to antibiotics.

Methods: This was an observational descriptive study. The data were collected from 130 urine samples in RSUD Prof. Dr. W.Z. Johannes during period of January-December 2017. Patients were diagnosed UTI by using Vitek 2 .

Results: We obtained 130 samples of urine culture in RSUD. Prof. Dr. W. Z. Johannes during period of January-December 2017. From
130 samples of urine culture, 83 samples showed growth of bacteria and fungi $(63,85 \%)$ whereas 47 samples showed no growth (36,15\%). From 83 growth samples, we identified 20 types of bacteria which include 4 types of gram positive bacteria, 16 types of gram negative bacteria and 1 type of fungi. The most common causes of UTI were $E$. coli $(22,89 \%)$, Candida albicans (10,84\%), Klebsiella pneumoniae ss pneumoniae $(9,64 \%)$ and Acinetobacter baumanii (6,02\%). Meropenem, gentamycin and amikacin were still sensitive to uropathogen. The most common antibiotics which were resistance to bacteria were ampicillin and ceftriaxone.

Conclusion: Escherichia coli is the most prevalence contribute to UTI in outpatient and inpatient. There were only three types of non-resistant antibiotic to uropathogens.

Keyword: Urinary tract infection, E. Coli, antibiotic sensitivity.

Cite This Article: Anggelia, V., Oktavia, C., Sutrisno, H., Indita, H. 2020. Pola Mikroba dan Sensitivitasnya Terhadap Antibiotik pada Pasien dengan Infeksi Saluran Kemih di RSUD Prof. Dr. W.Z. Johannes, Kupang Periode Januari-Desember 2017. Intisari Sains Medis 11(1): 382-387. D0I: 10.15562/ ism.v11i1.474

\section{ABSTRAK}

Latar Belakang: Infeksi saluran kemih (ISK) merupakan salah satu masalah kesehatan serius. Beberapa tahun belakangan ini, pengobatan ISK menjadi tantangan tersendiri bagi para klinisi karena tingginya angka resistensi antibiotik. Penelitian ini bertujuan untuk mengetahui pola mikroba dan senstivitasnya terhadap antibiotik.

Metode: Pada penelitian deskriptif observasional ini, didapatkan 130 sampel urin di RSUD Prof. Dr. W.Z. Johannes dari bulan JanuariDesember 2017 dimana pasien didiagnosis ISK melalui pemeriksaan dengan Vitek 2.

1,2Dokter umum, RSUD. Naibonat, Kupang, NTT, Indonesia ${ }^{3}$ Dpeartemen Penyakit dalam, RSUD. Prof. Dr. W.Z. Johannes, Kupang, NTT, Indonesia

${ }^{4}$ Instalasi Patologi Klinik, RSUD. Prof. Dr. W.Z. Johannes, Kupang, NTT, Indonesia

*Correspondence to: Vivi Anggelia, Dokter umum, RSUD. Naibonat, Kupang, NTT, Indonesia

Diterima: 02-04-2019

Disetujui: 03-03-2020

Diterbitkan: 01-04-2020

Kata kunci: infeksi saluran kemih, E. Coli, resistensi antibiotik ism.v11i1.474

\section{PENDAHULUAN}

Infeksi Saluran Kemih (ISK) merupakan masalah kesehatan yang sering terjadi dan mempengaruhi 150 juta orang setiap tahunnya di dunia. ${ }^{1}$ Angka
47 sampel menunjukan tidak adanya pertumbuhan (36,15\%). Dari 83 sampel yang tumbuh, teridentifikasi sebanyak 20 tipe bakteri dimana 4 tipe merupakan gram-positif dan 16 tipe gram negatif serta 1 tipe jamur. Penyebab terbanyak ISK adalah E. coli (22,89\%), Candida albicans (10,84\%), Klebsiella pneumoniae ss pneumoniae $(9,64 \%)$ dan Acinetobacter baumanii (6,02\%). Dimana antibiotik jenis meropenem, gentamisin dan amikasin masih sensitif untuk uropatogen. Sedangkan ampisilin dan seftriakson adalah jenis antibiotik yang memiliki angka resistensi tertinggi.

Kesimpulan: Escherichia coli adalah penyebab tersering ISK dan hanya ditemukan tiga jenis antibiotik yang masih sensitif untuk uropatogen.

Cite Pasal Ini: Anggelia, V., Oktavia, C., Sutrisno, H., Indita, H. 2020. Pola Mikroba dan Sensitivitasnya Terhadap Antibiotik pada Pasien dengan Infeksi Saluran Kemih di RSUD Prof. Dr. W.Z. Johannes, Kupang Periode Januari-Desember 2017. Intisari Sains Medis 11(1): 382-387. D0I: 10.15562/

kejadian ISK lebih tinggi pada anak-anak dan orang dewasa, dimana wanita dewasa 30 kali lebih rentan mengalami ISK daripada laki-laki. ${ }^{2}$ Menurut 
Departemen Kesehatan RI 2014, prevalensi kejadian ISK mencapai 90-100 kasus per 100.000 penduduk setiap tahunnya. ${ }^{3}$ Dalam perkembangannya, ISK menjadi semakin sulit diterapi, karena timbulnya resistensi antibiotic. Selain itu, extended-spectrum $\beta$-lactamase (ESBL) menyebabkan tingginya angka resistensi terhadap sebagian besar antibiotik, kecuali pada grup karbapenem. ${ }^{4}$

ISK merupakan infeksi pada saluran kemih yaitu ginjal, ureter, kandung kemih dan uretra. ${ }^{2}$ Secara klinis, ISK dikategorikan menjadi ISK tanpa komplikasi dan ISK dengan komplikasi. ISK tanpa komplikasi terjadi pada individu yang sehat dan tanpa kelainan struktural atau neurologi dari traktus urinarius. Sedangkan ISK dengan komplikasi terjadi pada individu dengan kelainan pada traktus urinarius atau pertahanan tubuh, mencakup obstruksi urinarius, retensi urin akibat kelainan neurologis, imunosupresan, gagal ginjal, transplantasi ginjal, kehamilan, dan adanya benda asing seperti kalkulus, dan pemasangan kateter. Secara anatomi, ISK dibedakan menjadi ISK bagian bawah (sistits) dan ISK bagian atas (pielonefritis). ${ }^{1,2}$

Pada sebagian besar kasus, ISK disebabkan oleh kolonisasi flora rektal dan perianal pada traktus urogenital. ${ }^{5}$ Organisme penyebab ISK berupa Uropathogenic Escherichia coli (UPEC), Klebsiella pneumoniae, Staphylococcus saprophyticus, Enterococcus faecalis, group B Streptococcus (GBS), Proteus mirabilis, Pseudomonas aeruginosa, Staphylococcus aureus, Enterococcus, Klebsiella, Pseudomonas, dan Enterococcus or Staphylococcus sp serta jamur Candida sp. ${ }^{1,5}$ Faktor risiko terjadinya ISK berupa jenis kelamin, riwayat ISK sebelumnya, infeksi daerah vagina, riwayat diabetes melitus, obesitas, kelainan genetik dan pemasangan kateter. ${ }^{1,2,5}$

Diagnosis ISK didasarkan pada klinis dan pemeriksaan penunjang. Tanda dan gejala ISK berupa disuria, frekuensi dan urgensi, sedangkan pemeriksaan penunjang berupa urinalisa dan kultur urin sebagai baku emas. ${ }^{4}$

Penatalaksanaan ISK pada umumnya tergantung apakah ISK komplikata atau tanpa komplikata. Prinsip penanganan ISK adalah pemberian antibiotik spektrum luas sedini mungkin. Penanganan dini yang tepat pada ISK dapat mencegah terjadinya urosepsis. ${ }^{2}$ Antibiotik yang direkomendasikan berupa florokuinolon, amoksisilin-klavulanat dan golongan aminoglikosida. ${ }^{2,4}$

Tujuan penelitian ini adalah untuk mengetahui pola bakteri penyebab ISK dan resistensi antibiotik pada bakteri penyebab ISK di RSUD. Prof. Dr. W.Z. Johannes.

\section{METODE}

Penelitian ini merupakan penelitian observasional deskriptif terhadap penderita ISK yang ada di RSUD. Prof. Dr. W.Z. Johannes meliputi pasien rawat jalan dan rawat inap pada periode Januari Desember 2017 yang diperiksakan urinnya di Instalasi Patologi Klinik. Bahan sampel urin segar diambil dari urin porsi tengah (midstream urine) yang kemudian dilakukan kultur urin dengan menggunakan alat pemeriksaan kultur otomatis "Vitek 2" Unit Instalasi Patologi Klinik RSUD Prof. W.Z. Johannes. Urin yang diambil dilakukan pewarnaan gram kemudian dibiakan dalam media padat seperti agar darah dan agar mac conkey. Setelah dapatkan koloni yang tumbuh, koloni tersebut dimasukan ke dalam tabung yang berisi cairan $\mathrm{NaCl}$ yang selanjutnya dimasukan kedalam alat kultur otomatis "Vitek 2", yang bertujuan untuk identifikasi bakteri dan pemerikssan sensitivitas bakteri terhadap antibiotik. Penelitian ini telah disetujui komite etik lokal departemen penyakit dalam RSUD. Prof. Dr. W.Z. Johannes, Kupang.

\section{HASIL}

Dari 128 pasien yang diperiksakan urinnya, didapatkan 103 sampel berasal dari pasien rawat inap dan 27 sampel dari pasien rawat jalan. Pasien wanita sebanyak 71 pasien dan laki-laki 57 pasien. Dari hasil tersebut didapatkan pasien yang mengalami ISK lebih banyak terjadi pada wanita daripada lakilaki (gambar 1).

Pemeriksaan kultur urin dari 130 sampel didapatkan 83 sampel mengalami pertumbuhan bakteri dan jamur dan 47 sampel tidak ada menunjukkan adanya pertumbuhan. Dari 83 sampel yang ada pertumbuhan teridentifikasi 20 jenis bakteri yang terdiri dari 4 bakteri gram positif dan 16 bakteri gram negative dan 1 jamur (tabel 1).

Distribusi hasil kultur urin dikelompokan berdasarkan asal pasien yang dapat dilihat pada (gambar 2-4). Terlihat E. coli merupakan penyebab utama ISK di RSUD. Prof. Dr. W.Z. Johannes baik pada pasien rawat jalan maupun rawat inap. Sedangkan pada pasien yang dirawat di ICU terlihat Candida albicans merupakan penyebab utama ISK. Bakteri lain yang tersering adalah Klebsiella pneumoniae ss pneumoniae dan Acinetobacter baumanii. Pemeriksaan uji sensitivitas bakteri terhadap antibiotik dapat dilihat pada tabel 2.

Dari tabel terlihat tidak ada antibiotik yang 100\% sensitif terhadap semua bakteri, namun gentamisin, meropenem dan amikasin masih sensitif terhadap 
Tabel 1 Data 83 sampel yang terdapat pertumbuhan

\begin{tabular}{|c|c|c|}
\hline ORGANISME & JUMLAH SAMPEL & PERSENTASE(\%) \\
\hline Staphylococcus coagulase negative & 20 & 24,09 \\
\hline Escherichia coli & 19 & 22,89 \\
\hline Candida albicans & 9 & 10,84 \\
\hline Klebsiella pneumoniae ss pneumoniae & 8 & 9,64 \\
\hline Acinetobacter baumanii & 5 & 6,02 \\
\hline Enterobacter cloacae & 4 & 4,82 \\
\hline Enterobacter, sp & 2 & 2,41 \\
\hline Enterococcus, sp & 2 & 2,41 \\
\hline Pseudomonas aeuriginosa & 2 & 2,41 \\
\hline Proteus mirabilis & 2 & 2,41 \\
\hline Pseudomonas fluorescens & 1 & 1,20 \\
\hline Kocuria kristinae & 1 & 1,20 \\
\hline Morganella morganii ss. Morganii & 1 & 1,20 \\
\hline Pseudomonas putida & 1 & 1,20 \\
\hline Burkholderia cepacia & 1 & 1,20 \\
\hline Serratia marcescens & 1 & 1,20 \\
\hline Serratia fonticola & 1 & 1,20 \\
\hline Citrobacter freundii & 1 & 1,20 \\
\hline Sphingomonas paucimobilis & 1 & 1,20 \\
\hline Staphylococcus aureus ss aureus & 1 & 1,20 \\
\hline Jumlah & 83 & 100 \\
\hline
\end{tabular}

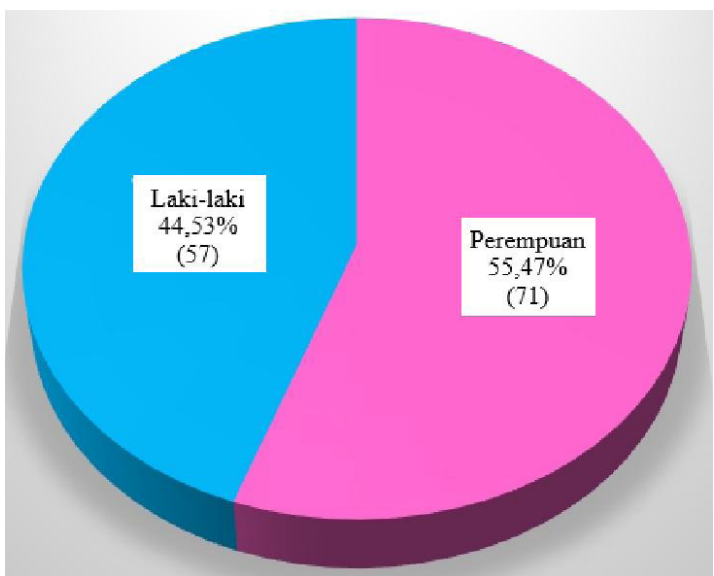

\section{Gambar 1 Distribusi pasien ISK berdasarkan jenis kelamin}

sebagian besar bakteri penyebab ISK, sedangkan ampisilin dan seftriakson hampir seluruh isolat menunjukan resistensi. Sedangkan gambar 5-8 menunjukkan persentase uji sensitivitas antibiotik pada 3 bakteri penyebab ISK tersering.

\section{PEMBAHASAN}

Berdasarkan hasil penelitian yang telah dilakukan pada 127 pasien ISK baik rawat jalan maupun

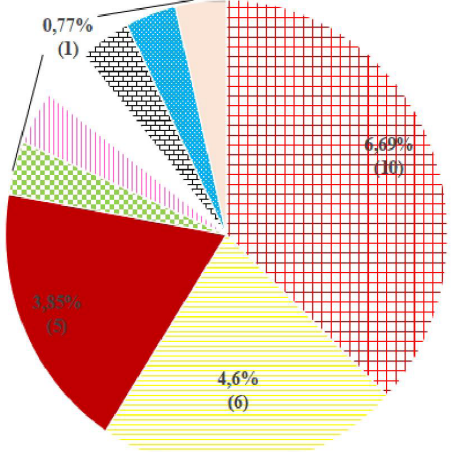

$\rightarrow$ No growth

E. Coli

- Stap. Coagulase negatif

Acinetobacter baumanii

|l Citrobacter freundii

Stap. Aureus ss aureus

工 s serratia fonticola

Klebsiella pneumoniae ss pneumoniae

Sphingomons paucimobilis

Gambar 2 Persentase kultur urin pada pasien ISK yang rawat jalan (total 27 sampel)

rawat inap di bangsal maupun di ICU RSUD. Prof. W.Z. Johannes periode Januari-Desember 2017 didapatkan bahwa ISK lebih banyak terjadi pada wanita yaitu 55,47\% (71 pasien) dibandingkan dengan laki-laki 44,53\% (57 pasien). Hal tersebut sesuai dengan penelitian yang dilakukan oleh Sumolang dkk, yang melaporkan bahwa wanita lebih sering menderita ISK dibanding dengan lakilaki. Hal tersebut berkaitan dengan sejumlah faktor predisposisi seperti struktur anatomis saluran kemih perempuan, riwayat kehamilan, menopause, aktifitas seksual dan lain-lain. Uretra perempuan 
Tabel 2 Hasil uji sensitivitas isolat bakteri gram positif dan gram negatif terhadap antibiotik

\begin{tabular}{|c|c|c|c|c|c|c|c|c|c|c|c|c|c|c|}
\hline Organisme & $\begin{array}{l}\text { Jumlah } \\
\text { isolat }\end{array}$ & $\begin{array}{c}\text { MEM } \\
\%\end{array}$ & $\begin{array}{c}\text { CAZ } \\
\%\end{array}$ & $\begin{array}{c}\text { CRO } \\
\%\end{array}$ & $\begin{array}{c}\text { AMC } \\
\%\end{array}$ & $\begin{array}{c}\text { CIP } \\
\%\end{array}$ & $\begin{array}{c}\text { SAM } \\
\%\end{array}$ & $\begin{array}{c}\text { SXT } \\
\%\end{array}$ & $\begin{array}{c}\text { TCY } \\
\%\end{array}$ & $\begin{array}{c}\text { GEN } \\
\%\end{array}$ & $\begin{array}{c}\text { CEP } \\
\%\end{array}$ & $\underset{\%}{\operatorname{AMX}}$ & $\underset{\%}{\text { AMP }}$ & $\underset{\%}{\mathrm{AMK}}$ \\
\hline Acinetobacter Baumanii & 5 & 25 & 20 & 0 & 0 & - & 100 & 80 & 0 & 60 & 50 & - & - & 100 \\
\hline Candida Albicans & 9 & - & - & - & - & - & - & - & - & - & - & - & - & - \\
\hline Citrobacter freundii & 1 & 100 & - & 0 & - & - & 0 & 0 & - & 100 & - & - & 0 & 0 \\
\hline Enterobacter cloace & 4 & 50 & 0 & 0 & - & - & 0 & 25 & - & 25 & - & - & 0 & 100 \\
\hline E. Coli & 19 & 100 & 55 & 44 & 66 & 60 & 27 & 16 & 18 & 66 & 25 & 50 & 11 & 75 \\
\hline Enterobacter sp. & 2 & 50 & 0 & 0 & 50 & - & 100 & 0 & 50 & 100 & 0 & - & - & - \\
\hline Enterococcus sp. & 2 & - & - & - & - & - & - & 0 & 0 & 100 & - & - & 0 & - \\
\hline Kocuria Kristinae & 1 & - & - & - & - & - & - & - & - & - & - & - & - & - \\
\hline $\begin{array}{l}\text { Klebsiella pneumoniae ss } \\
\text { pneumoniae }\end{array}$ & 8 & 100 & 12 & 12 & 100 & 50 & 12 & 50 & 0 & 62 & 0 & - & 0 & 85 \\
\hline $\begin{array}{l}\text { Morganella Morganii ss. } \\
\text { Morganii }\end{array}$ & 1 & 100 & 0 & 0 & - & 0 & 0 & 100 & - & 100 & - & - & 0 & 0 \\
\hline Pseudomonas Aeruginosa & 2 & 100 & 100 & - & - & - & - & - & - & 100 & - & - & - & - \\
\hline Burkholderia cepacian & 1 & - & - & - & - & - & - & - & - & - & - & - & - & - \\
\hline Pseudomonas fluorescens & 1 & 100 & 100 & - & - & - & - & - & - & 100 & - & - & - & - \\
\hline Proteus Mirabilis & 2 & 50 & 50 & 50 & - & - & 50 & 0 & - & 100 & - & - & 50 & 100 \\
\hline Pseudomonas putida & 1 & 100 & 0 & - & - & - & - & - & - & 100 & - & - & - & - \\
\hline $\begin{array}{l}\text { Staphylococcus Aureus ss } \\
\text { Aureus }\end{array}$ & 1 & - & - & - & - & - & - & 100 & 100 & 100 & - & - & - & - \\
\hline $\begin{array}{l}\text { Satohylococcus coagulase } \\
\text { negative }\end{array}$ & 20 & - & - & - & - & - & - & - & - & - & - & - & - & - \\
\hline Serratia Fonticola & 1 & 100 & 0 & 0 & - & 100 & 0 & 100 & - & 100 & - & - & 0 & 100 \\
\hline Serratia Marcescens & 1 & 100 & 0 & 0 & - & 100 & 0 & 100 & - & 0 & - & - & 0 & 100 \\
\hline $\begin{array}{l}\text { Sphingomonas } \\
\text { paucimobilis }\end{array}$ & 1 & - & - & - & - & - & - & - & - & - & - & - & - & - \\
\hline No growth & 47 & & & & & & & & & & & & & \\
\hline Total & 130 & & & & & & & & & & & & & \\
\hline
\end{tabular}

Keterangan;

${ }^{*}$ Persentase sensitivitas

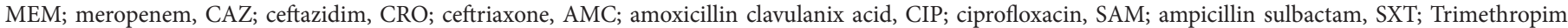
sulfamethoxazole, TCY; tetracycline, GEN; gentamycin, CEP;cephazolin, AMX; amoxicillin, AMP; ampicillin, AMK; Amikasin.

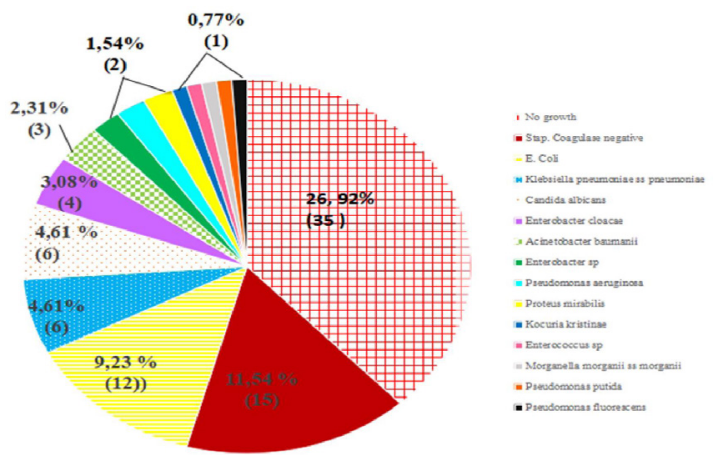

Gambar 3 Persentase kultur urin pada pasien ISK yang rawat di bangsal (total 92 sampel)

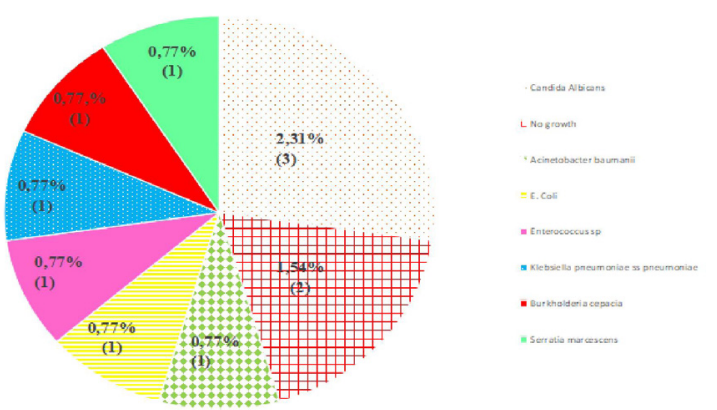

Gambar 4 Persentase kultur urin pada pasien ISK rawat inap di ruangan ICU (total 11 sampel) 


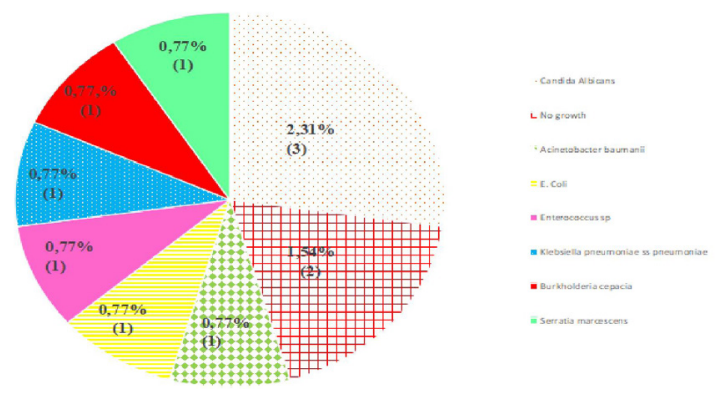

Gambar 5 Persentase uji sensitivitas bakteri E. coli terhadap antibiotik

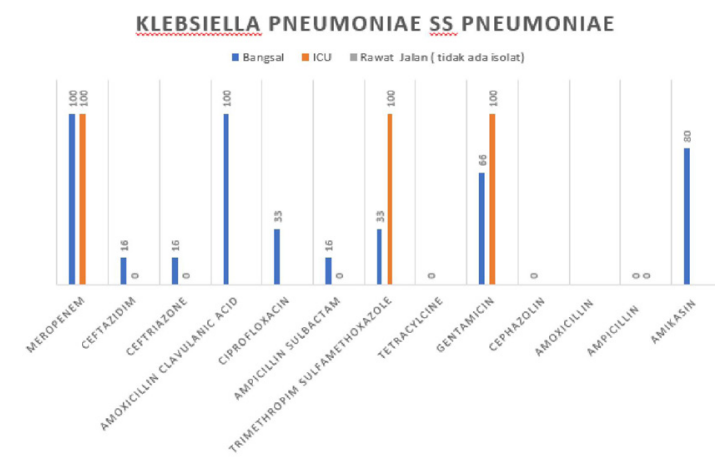

Gambar 6 Persentase uji sensitivitas bakteri Klebsiella pneumoniaess pneumonia terhadap antibiotik

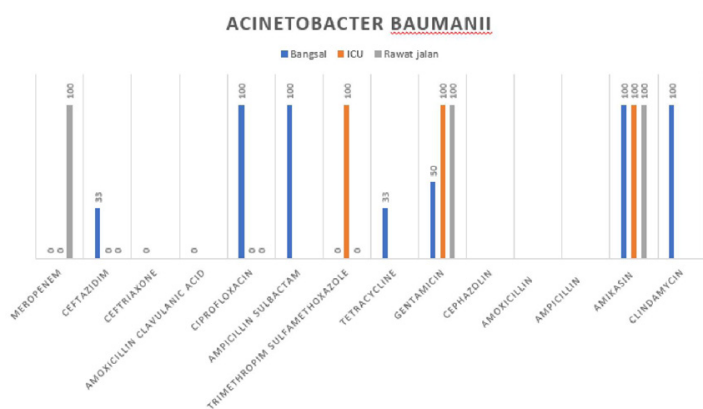

Gambar 7 Persentase uji sensitivitas bakteri Acinobacter baumanii terhadap antibiotik

yang pendek serta dekat dengan anus, mempermudah bakteri untuk naik ke dalam saluran kemih. Kehamilan juga dikaitkan dengan kejadian bakteriuria asimptomatis dan pielonefritis. ${ }^{6}$

Dari hasil kultur urin yang kami lakukan, ditemukan bakteri Staphylococcus coagulase negative dengan jumlah terbanyak, namun bakteri ini bukan merupakan penyebab ISK karena merupakan floral normal pada kulit dan merupakan salah satu kontaminan yang paling umum dari sampel yang dikirim ke laboratorium diagnostik dan penyebab utama infeksi yang terkait dengan penggunaan perangkat prostetik dan kateter. ${ }^{7}$ Pada hasil penelitian didapatkan penyebab tersering ISK berturutturut adalah E.coli, Candida albicans, Klebsiella pneumonia, Acinetobacter baumanii. Dimana Candida albicans menjadi penyebab tersering pasien ISK di ruangan ICU. Hasil tersebut sesuai dengan penelitian yang dilakukan oleh Mireles dkk pada tahun 2015 dan peneltian oleh Zeyaullah pada tahun 2017, yang menyebutkan bahwa penyebab ISK tersering adalah kuman E.coli dan Klebsiella pneumonia, namun pada penelitian yang dilakukan oleh Zeyaullah pada tahun 2017 tidak disebutkan adanya jamur Candida sebagai penyebab tersering ISK, terutama di ruangan ICU. ${ }^{8,9,10}$ Berbeda dengan penelitian oleh Spampinato A dan Leonardi D yang menyebutkan bahwa, Candida albicans merupakan penyebab tersering pada pasien diruangan ICU dengan angka kejadian 10-20 kali lebih sering dibanding dengan pasien non-ICU. Hal ini mungkin dikarenakan oleh faktor lamanya pasien di rawat inapkan di ruangan ICU, pasien dengan immunocompromise, dan riwayat penggunaan antibiotik spektrum luas sebelumnya. ${ }^{11}$

Pada uji sensitivitas isolat bakteri baik gram positif maupun gram negative menunjukkan bahwa tidak ada antibiotik yang 100\% sensitif terhadap semua bakteri penyebab ISK, namun didapatkan bahwa antibiotik gentamisin, meropenem dan amikasin masih cukup sensitif terhadap sebagian besar bakteri penyebab ISK, sedangkan antibiotik amipisilin dan ceftriakson menunjukkan resistensi terhadap sebagian besar bakteri penyebab ISK. Hal ini sesuai dengan penelitian yang dilakukan oleh Adhitya S di RS PKU Muhammadiyah Surakarta yang menyebutkan bahwa antibiotik golongan betalaktam (golongan penisilin dan sefalosporin), menunjukkan resitensi terhadap sebagian besar bakteri penyebab ISK. ${ }^{12}$

Antibiotik yang masih sensitif terhadap $E$. coli (dengan persentase $\geq 60 \%$ ) adalah meropenem, amikasin, gentamisin, amoksilin asam klavulanat dan ciprofloksasin. Sedangkan jenis antibiotik yang masih sensitif terhadap Klebsiella pneumoniae adalah meropenem, amoksilin asam klavulanat, amikasin, dan gentamisin. Antibiotik yang masih sensitif terhadap Acinetobacter baumanii adalah amikasin, ampisilin-sulbaktam, trimetropim-sulfametoksazol, dan gentamisin. Penelitian yang dilakukan oleh Adhitya S di RS PKU Muhammadiyah Surakarta juga melaporkan hal yang sama bahwa bakteri E. Coli masih sensitif terhadap antibiotik meropenem, amikasin, gentamisin, ciprofloksasin, sedangkan Klebsiella pneumoniae masih sensitif terhadap antibiotik amikasin dan gentamisin. ${ }^{12}$ Namun untuk uji sensitivitas meropenem terhadap bakteri Klebsiela pneumoniae, pada penelitian ini didapatkan masih $100 \%$ sensitif terhadap meropenem, hal ini sedikit berbeda dengan hasil penelitian Adhitya S yang 
menyebutkan hanya 50\% saja meropenem sensitif terhadap bakteri Klebsiela pneumoniae. ${ }^{12}$

\section{KESIMPULAN}

Kuman penyebab tersering ISK di RSUD. Prof. Dr. W.Z. Johannes periode Januari-Desember 2017, baik di rawat jalan maupun rawat inap adalah E. Coli. Namun penyebab utama ISK pada pasien yang dirawat di ICU adalah Candida albicans. Didapatkan pula bahwa semua kuman penyebab ISK menunjukkan adanya resistensi terhadap antibiotik.

\section{KONFLIK KEPENTINGAN}

Tidak ada konflik kepentingan pada penelitian ini.

\section{PENDANAAN}

Penelitian ini tidak mendapatkan pendanaan oleh pemerintah ataupun lembaga swasta lainnya.

\section{DAFTAR PUSTAKA}

1. Flores A.L, Walker J, Caparon M, et al. Urinary Tract Infections : Epidemiology, Menchanisms of Infection and Treatment Options. J Nat Rev Microbial. 2015 May; 13 (5): 269-284.

2. Tan C.W, Chlebicki M.P. Urinary Tract Infection in Adults. Singapore Med J. 2016; 57 (9) : 485-490.

3. Depkes RI. 2014. Survei Demografi dan Kesehatan Indonesia. Jakarta : Depkes RI.
4. Grabe M, Bartoletti R, Johansen B, et al. Guidelines on Urological Infections. European Association of Urology. 2015 March.

5. Sabih A, Leslie S.W. Urinary Tract Infections, Complicated. PubMed. 2017 Jan 31.

6. Sumolang S, Porotu'o J, Soeliongan S. Pola Bakteri pada Penderita Infeksi Saluran Kemih di BLU RSUP Prof.dr. R.D. Kandou Manado. Fakultas Kedokteran Universitas Sam Ratulangi.

7. Foster T. Chapter 12. Medical Microbiology. 4rd. ed. Baron S. Gaveston, Texas: University of Texas Medical Branch; 1996.

8. Vasudevan R. Urinary Tract Infection: An Overview of the Infection and the Associated Risk Factors. Journal of Microbiology \& Experimentation. 2014 May ;1(2):1-15.

9. Muhammad A, Nurulita AN, Budiman A. Uji Sensitivitas Antibiotik terhadap Bakteri Penyebab Infeksi saluran Kemih pada Pasien Rawat Inap di RSUD Prof. DR Margono Soekarjo Purwokerto. Pharmacy. 2017 Desember; 14 (2):247- 63.

10. Mireles A L, et al. Urinary Tract Infections: Epidemiology, Mechanisms of Infection and Treatment Options. Nat Rev Microbiol. 2015 May; 13(5): 269-284.

11. Spampinato A, Leonardi D. Candida Infections, Causes, Targets, and Resistance Mechanisms: Traditional and Alternative Antifungal Agents. Biomed Res Int. 2013 June: 1-3.

12. Adhitya S. Pola Kuman dan Resistensi Bakteri terhadap Antibiotik Pada Penderita ISK di Instalasi Rawat Inap RS PKU Muhammadiyah Surakarta Periode Febuari-Maret 2016. Fakultas Farmasi Universitas Muhammadiyah Surakarta. 2016.

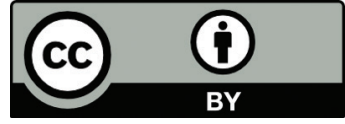

This work is licensed under a Creative Commons Attribution 